\title{
Preparation of antioxidant peptides from hairtail surimi using hydrolysis and evaluation of its antioxidant stability
}

\author{
Peixin WANG ${ }^{1,2}$, Yan $\mathrm{LIN}^{1}$, Hongqiang WU11, Jiaxin $\mathrm{LIN}^{1}$, Yueyu $\mathrm{CHEN}^{1}$, Siti Sarah HAMZAH ${ }^{3}$, Hongliang ZENG ${ }^{1,2}$, \\ Yi ZHANG ${ }^{1,2,4 *}$, Jiamiao $\mathrm{HU}^{1,2 *}$
}

\begin{abstract}
In this study, antioxidant peptides were prepared from hairtail surimi by hydrolysis. Response surface methodology coupled with a Box-Behnken design was applied to optimize hydrolysis conditions. The optimum conditions were determined as: $12.1 \mathrm{~h}$ incubation time, $44.74{ }^{\circ} \mathrm{C}$ incubation temperature and enzyme concentration $1858.85 \mathrm{U} / \mathrm{g}$. The amino acid compositions analysis showed most abundant amino acid in hairtail surimi antioxidant peptides (HAP) was Glutamic acid followed by Aspartic acid and Lysine. In addition, the fraction of HAP with a molecular weight less than $3 \mathrm{kDa}$ showed the strongest antioxidant activity among the 4 fractions obtained by ultrafiltration. Furthermore, HAP showed good stability in mild acidic, alkaline, or salt solutions, in in vitro digestive juice, and upon heating. In conclusion, hairtail surimi might be a good source to produce antioxidant peptides, which can be used as a natural antioxidant in food industry.
\end{abstract}

Keywords: antioxidant peptides; hairtail surimi; response surface methodology; antioxidant stability.

Practical Application: Used as ingredients in functional foods; or used as natural antioxidant for food preservation.

\section{Introduction}

Currently, the search for antioxidant peptides from natural sources has gained growing interests since antioxidant peptides can act as free radical scavengers, peroxide decomposers, metal inactivators, or oxygen inhibitors to protect the body against reactive oxygen species (ROS) (Xue et al., 2015). Besides, antioxidant peptides also showed great potential in applications as food additives (Taheri et al., 2014) to replace synthetic antioxidant such as propyl gallate (PG), butylated hydroxyanisole (BHA), butylated hydroxytoluene (BHT), and tert-butylhydroquinone (TBHQ) (Liu et al., 2018). Enzymatic hydrolysis method has been proven to be an effective way of extracting antioxidant peptides from various fish proteins. For example, previous reports have shown anchovy fish (Wang et al., 2018), tilapia (Sun et al., 2013), cod (Girgih et al., 2015), and croceine croaker fish (Chi et al., 2015) can be sources for extracting antioxidant peptides.

Hairtail is one of the most important marine commercial fish. The latest available data showed hairtail have accounted for $70-80 \%$ of global fish catches ( $\mathrm{Li}$ et al., 2016) due to the advantages of being low-cost and easy to obtain (Huang et al., 2015). As an innovation to revitalize fish industry and make better use of 'low-value fish', hairtail surimi is a convenient option because of its abundance and storability hence suitable for urban consumption and large-scale factory manufacturing. Therefore, there are great market prospects for natural antioxidant extract from hairtail surimi.
In this study, we explored the feasibility of extracting antioxidant peptides from Hairtail surimi (HAP) and optimized hydrolysis conditions using the response surface methodology coupled with a Box-Behnken design. Furthermore, ultrafiltration was also applied to separate the crude antioxidant peptides into different fractions according to their molecular weights and the antioxidant activities of different ultrafiltration fractions were compared. In addition, we also explored the stability of HAP in mild acidic, alkaline, or salt solutions, in in vitro digestive juice, and upon heating in this study.

\section{Materials and methods}

\subsection{Materials}

Hairtail surimi was obtained from Haixin Foods Co., Ltd (Fuzhou, Fujian, China) and immediately stored at $-20^{\circ} \mathrm{C}$ until use. Hairtail surimi was defatted according to the method by Klompong et al. (2007) before antioxidant peptides extraction (Additional information on methods in the Supplementary Material document). Total antioxidant capacity (T-AOC) kits were purchased from Comin Biotechnology Co., Ltd (Suzhou, Jiangsu, China). Pepsin (250 U/mg), trypsin (250 U/mg), dispase (60 U/mg), alkaline proteinase $(200 \mathrm{U} / \mathrm{mg})$, and bromelain $(500 \mathrm{U} / \mathrm{mg}$ ) were purchased from Solarbio Science \& Technology Co., Ltd (Beijing, China). 2,2-diphenyl-1-picryhydrazyl (DPPH) was purchased from Macklin Biochemical Co., Ltd (Shanghai, China). All other chemicals and reagents were of analytical grade. 


\subsection{Extraction of Hairtail Antioxidant Peptide (HAP)}

Hairtail surimi was subjected to enzymatic hydrolysis using pepsin, trypsin, dispase, alkaline proteinase, or bromelain according to the method described by Yang et al. (2019) (Supplementary Material Table 1). Then, the hydrolysis conditions were optimized using response surface methodology (RSM) (Design Expert V8.0.6 software, Stat-Ease Inc., USA) after Single-factor Test (Supplementary Material Table 2). In the experimental design, incubation time (X1), incubation temperature (X2), and enzyme concentration (X3) were selected as independent variables, and T-AOC (Y) was taken as the response variable. The levels of independent variables and the experimental design basing on a Box-Behnken design (BBD) was taken as the response (Supplementary Material Table 3 and 4).

\subsection{Analysis of amino acid composition}

Amino acid composition was determined using an L-8900 automatic Amino Acid Analyzer (Hitachi High-Technologies Co., Japan) equipped with a $60 \times 4.6 \mathrm{~mm}$ i.d., $1 \mu \mathrm{m}$ Hitachi ion exchange resin column, according to the method reported by Liu et al. (2015). Protein content was determined using automatic Kjeldahl apparatus (Kjeltec 8400, FOSS Co., Ltd, Denmark).

\subsection{Ultrafiltration}

Hydrolysates were filtered through ultrafiltration membranes (Vivaflow 200, Sartorius, Gottingen, Germany) with a molecular weight cut-off of 10,5 , and $3 \mathrm{kDa}$ sequentially at $4{ }^{\circ} \mathrm{C}$, powered by a peristaltic pump (Longer Precision Pump Co., Ltd, Baoding, China) at $65 \mathrm{rpm}$. The molecular weights of collected

Table 1. Analysis of Variance (ANOVA) for the response surface quadratic model used for the optimization of hairtail surimi hydrolysate.

\begin{tabular}{|c|c|c|c|c|c|c|}
\hline Source & $\begin{array}{c}\text { Sum } \\
\text { of Squares }\end{array}$ & $\mathrm{df}$ & Mean Square & $\begin{array}{c}\mathrm{F} \\
\text { Value }\end{array}$ & $\begin{array}{c}\text { p-value } \\
\text { Prob }>\text { F }\end{array}$ & Significance \\
\hline Model & 77.29 & 9 & 8.59 & 32.55 & $<0.0001$ & $* *$ \\
\hline $\mathrm{X}_{1}$ & 0.036 & 1 & 0.036 & 0.13 & 0.7245 & \\
\hline $\mathrm{X}_{2}$ & 0.93 & 1 & 0.93 & 3.52 & 0.1029 & \\
\hline $\mathrm{X}_{3}$ & 4.56 & 1 & 4.56 & 17.29 & 0.0043 & $* *$ \\
\hline $\mathrm{X}_{1} \mathrm{X}_{2}$ & $2.19 \times 10^{-4}$ & 1 & $2.19 \times 10^{-4}$ & $8.303 \times 10^{-4}$ & 0.9778 & \\
\hline $\mathrm{X}_{2} \mathrm{X}_{3}$ & 0.33 & 1 & 0.33 & 1.26 & 0.2980 & \\
\hline $\mathrm{X}_{1}^{2}$ & 31.24 & 1 & 31.24 & 118.40 & $<0.0001$ & ** \\
\hline $\mathrm{X}_{2}^{2}$ & 24.21 & 1 & 24.21 & 91.77 & $<0.0001$ & $* *$ \\
\hline $\mathrm{X}_{3}^{2}$ & 7.30 & 1 & 7.30 & 27.68 & 0.0012 & $* *$ \\
\hline Residual & 1.85 & 7 & 0.26 & & & \\
\hline
\end{tabular}

Table 2. The amino acid composition of hairtail surimi and HAP.

\begin{tabular}{|c|c|c|c|c|}
\hline & \multicolumn{2}{|c|}{ Hairtail Surimi } & \multicolumn{2}{|c|}{ HAP } \\
\hline & $\begin{array}{l}\text { Concentration ( } \mathrm{g} \text { amino } \\
\text { acid/kg hairtail surimi) }\end{array}$ & Composition (\%) & $\begin{array}{c}\text { Concentration ( } \mathrm{g} \text { amino } \\
\text { acid/kg HAP) }\end{array}$ & Composition (\%) \\
\hline Protein Content (g/100 g) & 43.5 & & 70.2 & \\
\hline Asp & 40.9 & 9.76 & 71.2 & 11.10 \\
\hline Thr & 22.4 & 5.35 & 36.5 & 5.69 \\
\hline Ser & 18.8 & 4.49 & 26.3 & 4.10 \\
\hline Glu & 69.5 & 16.59 & 114.0 & 17.78 \\
\hline Gly & 15.1 & 3.60 & 26.5 & 4.13 \\
\hline Ala & 27 & 6.44 & 40.6 & 6.33 \\
\hline Val & 18.2 & 4.34 & 23.8 & 3.71 \\
\hline Met & 14.3 & 3.41 & 21.0 & 3.27 \\
\hline Ile & 18.5 & 4.42 & 27.8 & 4.33 \\
\hline Leu & 36 & 8.59 & 52.7 & 8.22 \\
\hline Tyr & 19.4 & 4.63 & 24.0 & 3.74 \\
\hline Phe & 17.5 & 4.18 & 20.1 & 3.13 \\
\hline Lys & 39.3 & 9.38 & 78.2 & 12.19 \\
\hline His & 9.3 & 2.22 & 13.5 & 2.11 \\
\hline Arg & 29 & 6.92 & 38.3 & 5.97 \\
\hline Pro & 23.8 & 5.68 & 26.8 & 4.18 \\
\hline
\end{tabular}


peptide fractions were $<3 \mathrm{kDa}\left(\mathrm{F}_{1}\right), 3-5 \mathrm{kDa}\left(\mathrm{F}_{2}\right), 5-10 \mathrm{kDa}\left(\mathrm{F}_{3}\right)$, and $>10 \mathrm{kDa}\left(\mathrm{F}_{4}\right)$. All fractions were lyophilized and stored in a dryer until further use.

\subsection{GPC-MALLS analysis}

The molecular weight distribution of HAP was analyzed by MALLS system (Wyatt Technology, Santa Babara, USA) equipped with gel permeation chromatography (GPC) according to the method reported by Tiroli-Cepeda et al. (2018) (Additional information on methods in Supplementary Material document).

\subsection{Antioxidant assays}

DPPH radical scavenging activity was measured according to the method reported by Wu et al. (2003) with some modifications. Hydroxyl radical scavenging activity was determined according to the method by Jin et al. (2016) with some modifications. The total antioxidant capacity of HAP was measured using a total antioxidant capacity kit. The T-AOC reflects the ability to reduce $\mathrm{Fe}^{3+}$-TPTZ to produce blue $\mathrm{FE}^{2+}$-TPTZ in an acidic environment. The $\mathrm{IC}_{50}$ value was defined as the concentration of peptide fraction required to scavenge $50 \%$ of radical activity (Tanzadehpanah et al., 2012). The details are provided in Supplementary Material document.

\subsection{In Vitro gastrointestinal digestion}

The stability of HAP against the gastrointestinal proteases pepsin and trypsin was assessed in vitro according to the previously published method of Zhu et al. (2008) with some modifications. Peptide solutions were adjusted to $\mathrm{pH} 1.5$ using $1 \mathrm{M} \mathrm{HCl}$, and pepsin was added to the solution at a ratio of $1 \%$ of the total peptide content. The mixture was mixed vigorously and incubated at $37^{\circ} \mathrm{C}$ for 2 hours, then the mixture was heated in a boiling water bath for 10 minutes. The mixture was then cooled to room temperature, adjusted to $\mathrm{pH} 7.0$ with $1 \mathrm{M} \mathrm{NaOH}$, and centrifuged at $3000 \mathrm{rpm}$ for $10 \mathrm{~min}$. The supernatant was divided into two parts: one part was lyophilized and the other was adjusted to pH 7.5 with $1.0 \mathrm{M} \mathrm{NaOH}$, and trypsin was added to the solution at a ratio of $1 \%$ of the total peptide content. The mixture was mixed vigorously and incubated at $37^{\circ} \mathrm{C}$ for 4 hours. Samples were taken from the mixture every 1 hour and heated in a boiling water bath for 15 minutes, then cooled to room temperature, adjusted to $\mathrm{pH} 7.0$, and centrifuged at $3000 \mathrm{rpm}$ for $10 \mathrm{~min}$. The supernatant was subsequently lyophilized. All freeze-dried samples were dissolved at the concentration of $2.5 \mathrm{mg} / \mathrm{ml}$. The DPPH radical scavenging activity was measured soon afterwards.

\subsection{Statistical analysis}

Statistical analysis was carried out using Graphpad Prism 8.0.1 (Graphpad Softwarer Inc., San Diego, USA). All results were obtained from at least three independent experiments and expressed as mean \pm SEM. Results were analyzed using one-way analysis of variance, followed by Tukey test with a level of significance threshold of at least $\mathrm{p}<0.05$.

\section{Results and discussion}

\subsection{Protease selection}

The T-AOC of hydrolysate using different proteases were shown in Figure 1a. In general, the T-AOC of hydrolysates showed upward trends as the incubation time increased from 2 to $10 \mathrm{~h}$ except in alkaline proteinase-treated group. In addition, the T-AOC of the dispase-treated group was significantly higher than pepsin, trypsin, alkaline proteinase or bromelain-treated groups $(\mathrm{P}<0.05)$. This indicated that dispase could be very effective in releasing potent antioxidant peptides from hairtail surimi, therefore, dispase was chosen in the subsequent experiments.

\subsection{Single-factor tests}

\section{(1) Effect of Incubation Time on T-AOC of Hairtail Surimi Hydrolysate}

As shown in Figure 1b, when incubation temperature and enzyme concentration were fixed at $50{ }^{\circ} \mathrm{C}$ and $1000 \mathrm{U} / \mathrm{g}$, the T-AOC of hairtail surimi hydrolysate increased with the increasing incubation time and reached the maximum value $(23.98 \pm 0.97 \mathrm{U} / \mathrm{mL})$ at 12 hours.

\section{(2) Effect of Incubation Temperature on the T-AOC of Hairtail Surimi Hydrolysate}

The effect of incubation temperature on the T-AOC of hairtail surimi hydrolysate was shown in Figure 1c. At a fixed incubation time of 6 hours and enzyme concentration of $1000 \mathrm{U} / \mathrm{g}$, the $\mathrm{T}$-AOC of hairtail surimi hydrolysate reached the maximum value $(30.22 \pm 1.32 \mathrm{U} / \mathrm{mL})$ when incubation temperature was $45^{\circ} \mathrm{C}$.

\section{(3) Effect of Enzyme Concentration on T-AOC of Hairtail Surimi Hydrolysate}

As shown in Figure 1d, when incubation time and incubation temperature were fixed at 6 hours and $50{ }^{\circ} \mathrm{C}$, the maximum T-AOC of hairtail surimi hydrolysate $(36.74 \pm 0.59 \mathrm{U} / \mathrm{mL})$ was obtained in the samples hydrolyzed by dispase at $1800 \mathrm{U} / \mathrm{g}$, which was significantly higher than the T-AOC of all the other groups except the samples treated with $2000 \mathrm{U} / \mathrm{g}$ of enzyme $(\mathrm{p}<0.05)$.

Based on these results, an incubation time of 12 hours, incubation temperature of $45^{\circ} \mathrm{C}$, and enzyme concentration of $1800 \mathrm{U} / \mathrm{g}$ were adopted as center point for further response surface methodology (RSM) experimental design.

\subsection{Optimization of HAP hydrolysis conditions}

\section{(1) Statistical Analysis and Model Fitting}

Next, RSM was adopted to optimize the hydrolysis conditions for the preparation of antioxidant peptides from hairtail surimi. A quadratic model was used for process order and the statistical analysis for the linear, the quadratic, and the interaction of the three variables (X1, X2 and X3, respectively) on the response values $(\mathrm{Y})$, and the data was shown in Table 1 . The model was significant while the lack of fit was not significant, which indicated 

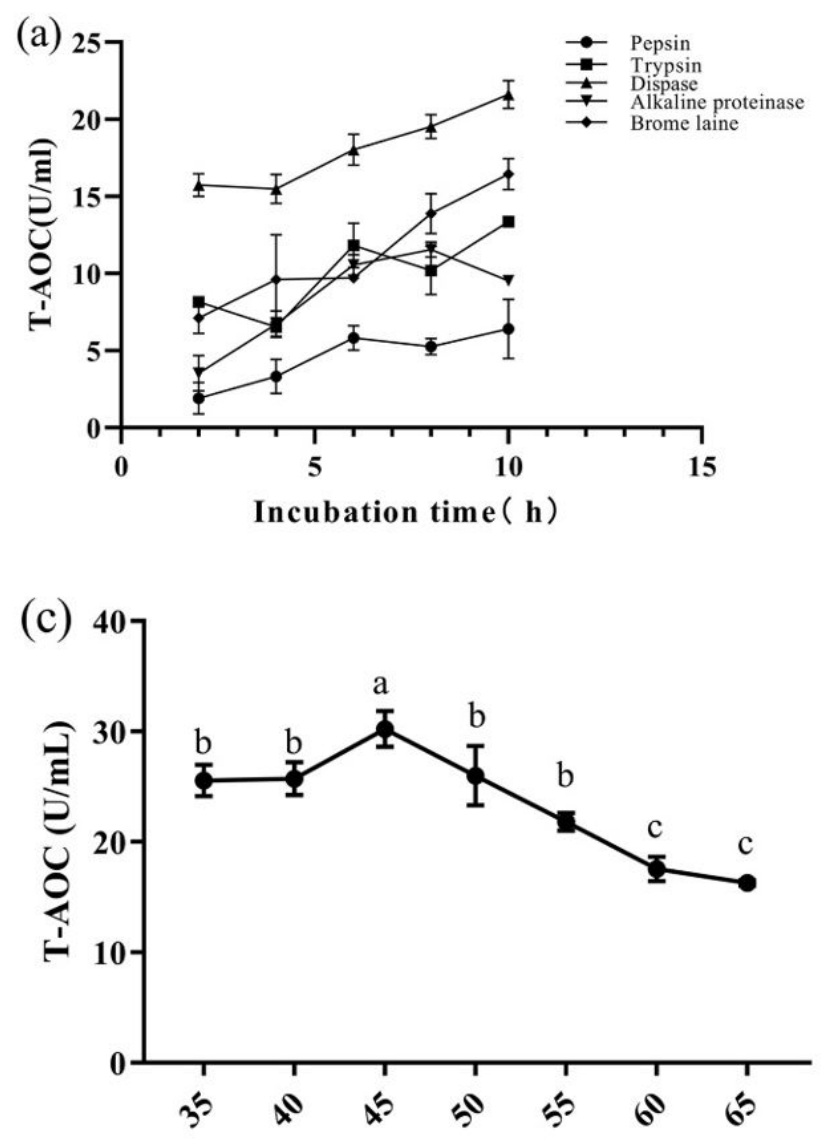

Incubation temperature $\left({ }^{\circ} \mathrm{C}\right)$
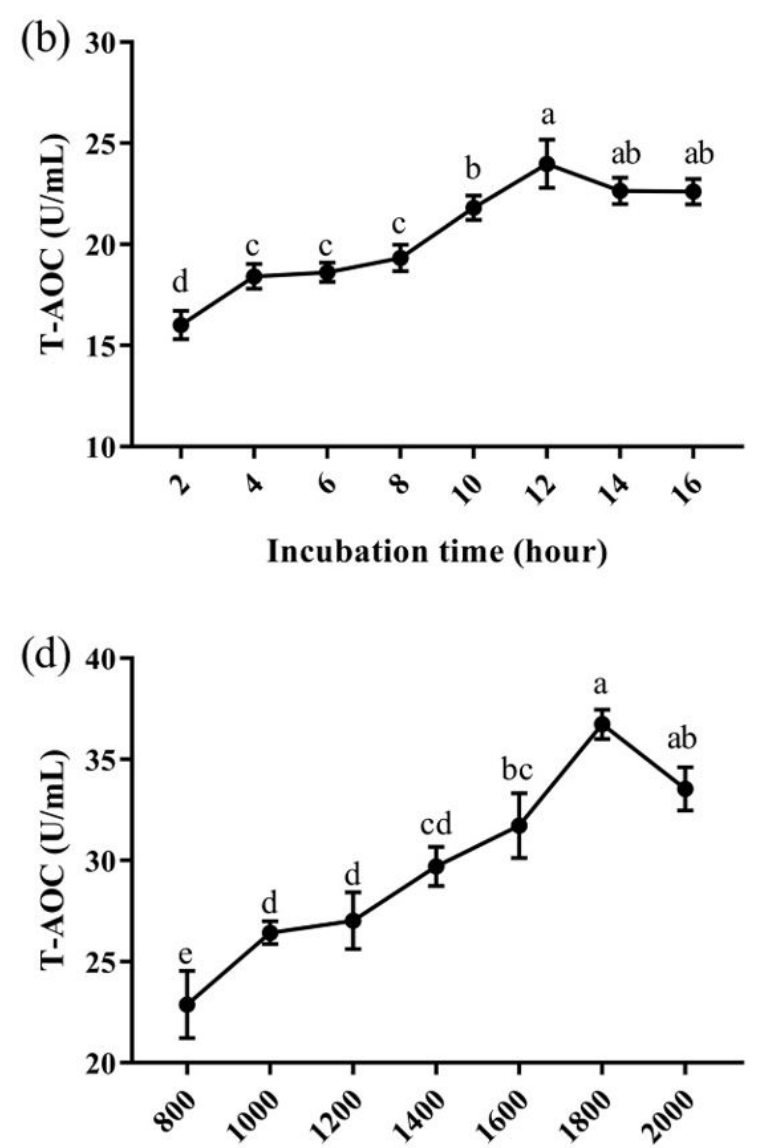

Enzyme concentration(U/g protein)

Figure 1. Effect of different extraction parameters on the T-AOC of hydrolysate from hairtail surimi. (a) Proteases; (b) Incubation time; (c) Incubation temperature; (d) Enzyme concentration.

that the model could be used to guide the optimization (Ren et al., 2008). Among the three linear terms, enzyme concentration had the greatest significant effect on the T-AOC $(\mathrm{p}<0.01)$. However, incubation time and incubation temperature were not significant. This indicated that enzyme concentration had a relatively greater significant effect on the T-AOC of the hairtail surimi hydrolysate compared to incubation time and incubation temperature. The effects of three quadratic terms $\mathrm{X}_{1}^{2}, \mathrm{X}_{2}^{2}$ and $\mathrm{X}_{3}{ }^{2}$ were all significant $(\mathrm{p}<0.01)$, and this illustrated that they were the significant factors in influencing the response (Yuan et al., 2018). The interaction term $X_{1} X_{3}$ was significant $(p<0.05)$ and this illustrated that that the interaction between incubation time and enzyme concentration significantly affected the T-AOC (Yuan et al., 2018). By using multiple regression analysis on the experimental data, the response variable and the independent variables were related by the following second-order polynomial Equation 1:

$$
\begin{aligned}
& Y=30.84+0.067 X_{1}-0.34 X_{2}+0.76 X_{3}-\left(7.4 \times 1010^{-3}\right) X_{1} X_{2}+ \\
& 0.72 X_{1} X_{3}+0.29 X_{2} X_{3}-2.72 X_{1}^{2}-2.40 X_{2}^{2}-1.32 X_{3}^{2}
\end{aligned}
$$

The model had a high determination coefficient $\left(\mathrm{R}^{2}=0.9767\right)$, which indicated that only $2.33 \%$ of the total variations were not explained by the model. The value of the adjusted determination coefficient (adjusted $\mathrm{R}^{2}=0.9467$ ) also confirmed that the model was highly significant.

\section{(2) The Effect of Incubation Time and Incubation Temperature on the Response Value}

The effect of incubation time $\left(\mathrm{X}_{1}\right)$ and incubation temperature $\left(\mathrm{X}_{2}\right)$ were demonstrated in the three-dimensional response surface plot (Figure 2a) and two-dimensional contour plot (Figure $2 \mathrm{~d}$ ), where the enzyme concentration $\left(\mathrm{X}_{3}\right)$ was fixed at 0 level. T-AOC of hairtail surimi hydrolysate increased as incubation time increased, but beyond $12.1 \mathrm{~h}, \mathrm{~T}$-AOC decreased with an increase in incubation time. Initially, hydrolysis might release antioxidant peptides and increase the antioxidant activity of the hydrolysate, but excessive hydrolysis time might cause the hydrolysis of antioxidant peptides into amino acids and destroy their antioxidant activity (Ren et al., 2008). The shape of the two-dimensional contour plot reflected the strength of the interaction between two factors: an oval showed stronger interaction effects while a circle showed weaker interaction effects (Chouaibi et al., 2018). As shown in Figure 2d, the interaction between incubation time and incubation temperature was not significant in a circular contour plot within a $95 \%$ confidence interval. 

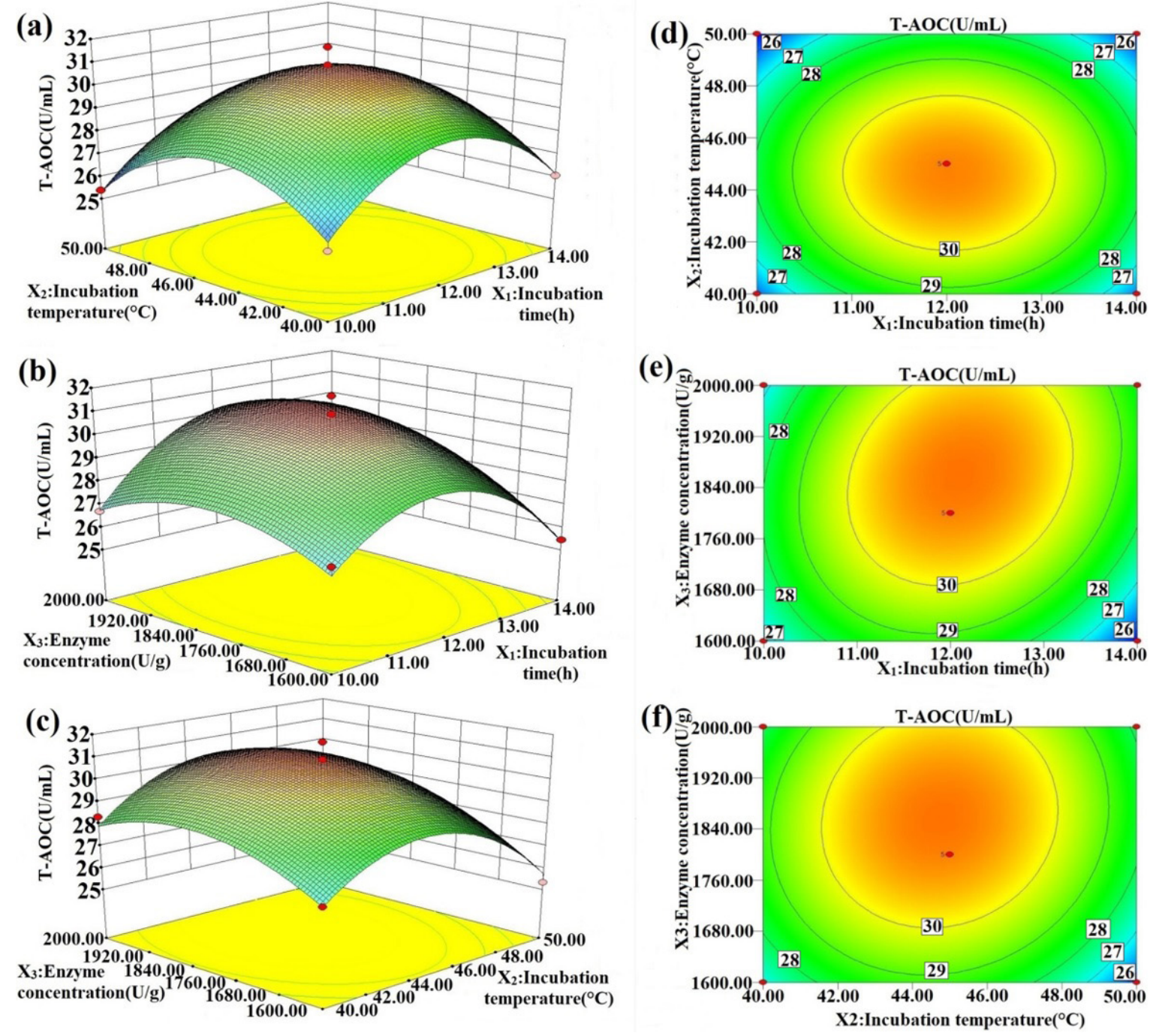

Figure 2. The three-dimensional response surface plots and two-dimensional contour plots of the relative effects on the T-AOC of HAP. (a) and (d): Incubation time and incubation temperature; (b) and (e): Incubation time and enzyme concentration; (c) and (f): Incubation temperature and enzyme concentration.

\section{(3) The Effect of Incubation Time and Enzyme Concentration on the Response Value}

The effects of incubation time $\left(\mathrm{X}_{2}\right)$ and enzyme concentration $\left(\mathrm{X}_{3}\right)$ are shown in the three-dimensional response surface plot (Figure 2b) and two-dimensional contour plot (Figure 2e), where the incubation time $\left(\mathrm{X}_{1}\right)$ was constant at 0 level. At first, T-AOC increased slowly with the increase in enzyme concentration, but the interaction between incubation time $\left(\mathrm{X}_{1}\right)$ and enzyme concentration $\left(\mathrm{X}_{3}\right)$ was significant; greater T-AOC values were obtained at high enzyme concentrations. The highest T-AOC value occurred within the enzyme concentration $1840-1860 \mathrm{U} / \mathrm{g}$, and T-AOC declined at greater concentrations. Zheng et al. (2018) reported that the reduction in antioxidant activities caused by high enzyme concentrations might be ascribed to the re-cleavage of antioxidative fractions, or the occurrence of enzyme inhibition. As shown in Figure 2e, the interaction between incubation time and enzyme concentration was strong, showing an oval contour plot.

\section{(4) The Effect of Incubation Temperature and Enzyme Concentration on the Response Value}

The effects of incubation temperature $\left(\mathrm{X}_{2}\right)$ and enzyme concentration $\left(\mathrm{X}_{3}\right)$ were shown in the three-dimensional response surface plot (Figure 2c) and two-dimensional contour plot (Figure $2 \mathrm{f}$ ), where the incubation time $\left(\mathrm{X}_{1}\right)$ was constant at 0 level. At first, T-AOC increased slowly with the increase in incubation temperature, but beyond $44.5-44.8^{\circ} \mathrm{C}$, T-AOC decreased with an increase in incubation temperature. This was similar to research reported by Fang et al. (2012). As shown in Figure $2 \mathrm{f}$, the interaction between incubation temperature $\left(\mathrm{X}_{2}\right)$ and enzyme concentration was not significant and showed a circular contour plot.

In conclusion, optimal hydrolysis conditions for hairtail surimi hydrolysate were: incubation time $12.1 \mathrm{~h}$, incubation temperature $44.74{ }^{\circ} \mathrm{C}$ and enzyme concentration $1858.85 \mathrm{U} / \mathrm{g}$ based on the results of this study. 
Among the three independent variables, enzyme concentration was the most significant factor affecting the T-AOC of hairtail surimi hydrolysate quadratic polynomial model (Table 1), three-dimensional response surface plot, and two-dimensional contour plot (Figure 2). In optimal conditions, the predicted T-AOC was $30.9618 \mathrm{U} / \mathrm{mL}$. The experiment was performed at optimal conditions. When the experiment was carried out at optimal conditions, the T-AOC was $29.7085 \pm 0.9226 \mathrm{U} / \mathrm{mL}$. This result confirmed that the model was suitable for the estimation of experimental values.

\subsection{Analysis of amino acid composition}

The amino acid compositions of hairtail surimi and HAP were presented in Table 2 . The results showed the hydrolysis process only slightly altered the amino acid composition between surimi and hydrolysate. The top five amino acids contained in HAP were Glu, Lys, Asp, Leu and Arg. Previous studies have confirmed that amino acid composition has a great influence on antioxidant activity. He et al. (2013) showed that negatively charged amino acids (ASX-aspartic acid and asparagine; GLX-glutamic acid and glutamine) had strong antioxidant effects due to their excess electrons and could act as hydrogen donors. Histidine imidazolyl could quench free radicals and chelate metal ions, and Leu and Pro could promote the antioxidant activity (Liu et al., 2015). Therefore, our obtained results (HAP being riched in Asp, Glu, Leu) may explain, at least partially, the antioxidant activities of HAP.

\subsection{GPC-MALLS analysis}

HAP was further analyzed for molecular weight distribution (Figure 3 ) which revealed that HAP were mainly composed of peptides with low molecular weight. The peptides were divided into five fractions according to the differential refractive index
(dRI) value. Their average molecular weights $(\mathrm{Mw})$ were 12.45 , $4.549,2.913,2.212$, and $1.166 \mathrm{kDa}$, respectively. While their number molar masses (Mn) were 7.457, 2.728, 1.455, 1.154, and $0.5322 \mathrm{kDa}$, respectively. The mass fractions of these five fractions were $1.1572,4.8851,9.4850,12.1709$, and $73.0681 \%$. In addition, results also indicated that HAP mainly contained a fraction with a mean Mw of $1.166 \mathrm{kDa}$, similar to a polypeptide isolated from skin of Scomberomorus niphonius that ranged between 1.426-1.810 kDa (Fu et al., 2019).

\subsection{Antioxidant activities of HAP and various ultrafiltration fractions}

Based on GPC-MALLS analysis results, we further separated the HAP into 4 fractions based on their molecular weights and compared their antioxidant activities. As shown in Figure $4 \mathrm{a}$ and $\mathrm{b}$, the $<3 \mathrm{kDa}$ fraction $\left(\mathrm{F}_{1}\right)$ possessed the highest $\mathrm{DPPH}$ radical scavenging rate, hydroxyl radical scavenging rate with the $\mathrm{IC}_{50}$ value of $1.74 \pm 0.07 \mathrm{mg} / \mathrm{mL}, 2.52 \pm 0.06 \mathrm{mg} / \mathrm{mL}$, respectively. Similarly, as shown in Figure $4 \mathrm{c}$, the $<3 \mathrm{kDa}$ fraction $\left(\mathrm{F}_{1}\right)$ also possessed the highest T-AOC when compared with other groups at the concentration of $5,10,15,20$, and $25 \mathrm{mg} / \mathrm{mL}(\mathrm{p}<0.05)$. Previous study has suggested that smaller molecular weight peptides may interfere with the progress of free radical reactions more effectively (Fan et al., 2012). Here, the smaller molecular weight peptides with a molecular weight less than $3 \mathrm{kDa}$ yielded the greatest antioxidant capacity, which were similar to the studies of Park et al. (2010), Ghassem et al. (2017), Intiquilla et al. (2019), Liu et al. (2017), and Meshginfar et al. (2018). This might be because the $<3 \mathrm{kDa}$ fraction was more accessible to the radicals, and could trap radicals more easily (Wang et al., 2013). Smaller peptides have more side exposed chains that could donate electrons and become more easily accepted by $\mathrm{Fe}^{3+}-\mathrm{TPTZ}$ complexes (Wiriyaphan et al., 2015).

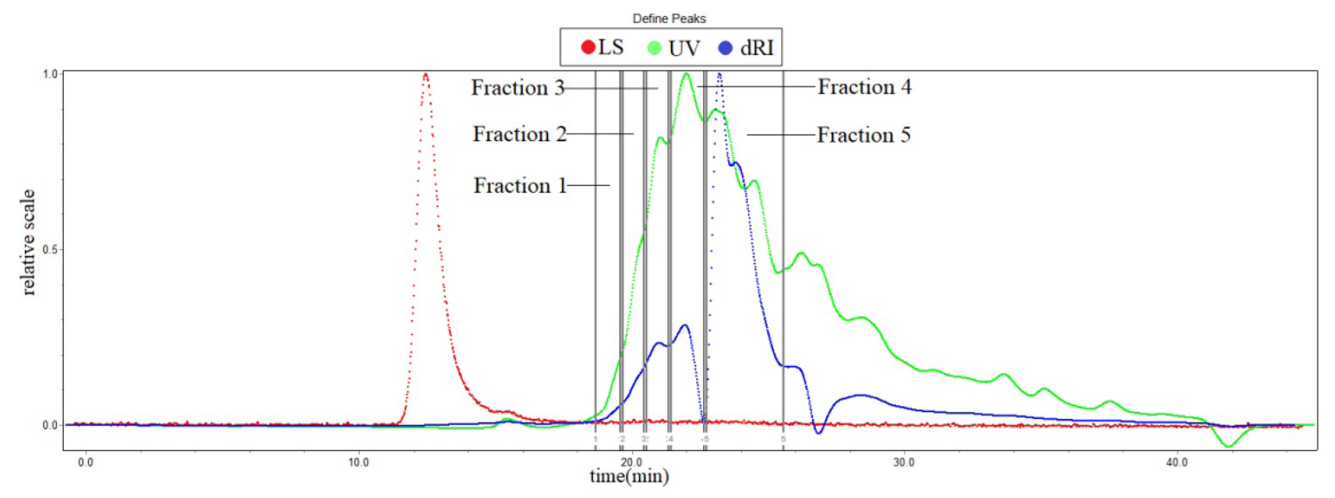

\begin{tabular}{lccccc}
\hline & Fraction 1 & Fraction 2 & Fraction 3 & Fraction 4 & Fraction 5 \\
\hline $\begin{array}{l}\text { Peak limits } \\
(\mathrm{min})\end{array}$ & $\begin{array}{c}18.667- \\
19.568\end{array}$ & $\begin{array}{c}19.662- \\
20.531\end{array}$ & $\begin{array}{c}20.438- \\
21.339\end{array}$ & $\begin{array}{c}21.432- \\
22.644\end{array}$ & $22.737-$ \\
Mass & $1.1572 \%$ & $4.8851 \%$ & $9.4850 \%$ & $12.1709 \%$ & $73.0681 \%$ \\
Fraction & & & & & \\
$\mathrm{Mn}(\mathrm{kDa})$ & 7.457 & 2.728 & 1.455 & 1.154 & 0.5322 \\
$\mathrm{Mw}(\mathrm{kDa})$ & 12.45 & 4.549 & 2.913 & 2.212 & 1.166 \\
\hline
\end{tabular}

Figure 3. Plots of refractive index increments of HAP determined using a GPC/MALLS system 

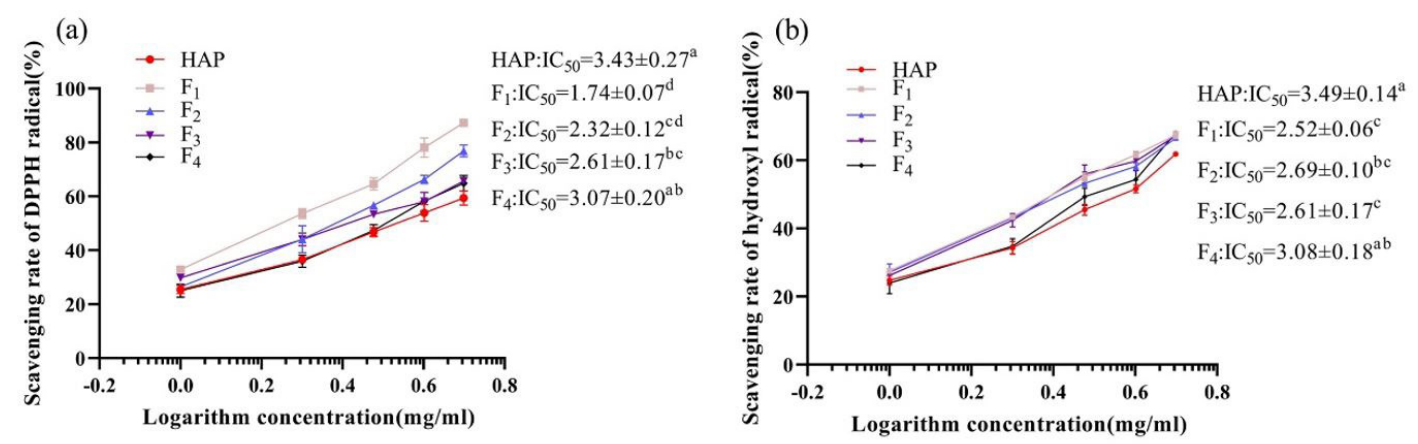

(c)

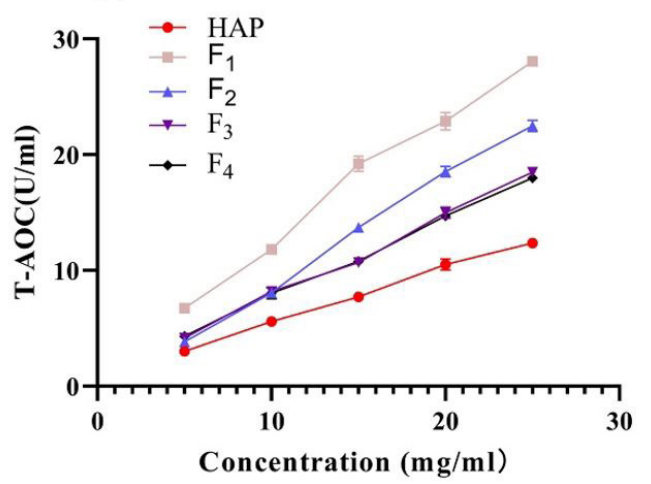

Figure 4. DPPH radical scavenging rate (a), hydroxyl radical scavenging rate (b) and T-AOC (c) of HAP and ultrafiltration fractions at different concentrations.

\subsection{The effects of $p H$, temperature and salt on antioxidant stability of HAP}

As shown in Figure 5a, the DPPH scavenging rate of HAP showed no significant change in solution with $\mathrm{pH}$ of 4,6 and 8; while DPPH scavenging rates decreased significantly $(\mathrm{p}<0.05)$ at highly acidic $(\mathrm{pH}=2)$ or highly alkaline $(\mathrm{pH}=12)$. The loss of activity could be the result of intramolecular cleavage in acidic solution or deamidation in alkaline solution. Oliyai \& Borchardt (1993) reported that the Asp-hexapeptide decomposed into two parts, including a tetrapeptide (Val-Tyr-Pro-Asp) and a dipeptide (Gly-Ala), via intramolecular cleavage under highly acidic conditions ( $\mathrm{pH}$ 0.3-3.0); while Patel \& Borchardt (1990) reported that deamidation has strong dependence on $\mathrm{pH}$, and the rate constants of deamidation increase with increasing $\mathrm{pH}$ in the region of $\mathrm{pH} 5$ to 12 .

As shown in Figure 5b, HAP also showed no significant changes in DPPH scavenging rates even when the incubation temperatures were up to $60^{\circ} \mathrm{C}$. Further increase in incubation temperature led to significant decrease in HAP DPPH scavenging activity. The decrease in antioxidant activity of the peptide under high temperature conditions was also reported by previous study Jang et al. (2016). This phenomenon might be due to the destruction of the secondary structure of peptide. In a previous study reported by Ye et al. (2008), it was found that $\beta$-sheet structure content of self-assembling peptide RADA 16-I solutions decreased by $11.3 \%$ when heat-denatured up to $80^{\circ} \mathrm{C}$.

The effects of salt concentration on HAP antioxidant activity were further investigated. All groups of HAP in the presence of
$\mathrm{NaCl}$ had a lower DPPH scavenging activity compared to control group. When the concentration of $\mathrm{NaCl}$ exceeded $4 \%$, the activity decreased with subsequent increases in $\mathrm{NaCl}$ concentration (Figure 5c). This change was consistent with previous findings of Jang et al. (2016). Zhu et al. (2014) reported that high $\mathrm{NaCl}$ content might disrupt the specific peptide structure and amino acid side chain groups responsible for chelation of transition metal ions.

\subsection{The effects of in Vitro gastrointestinal digestion on antioxidant stability of HAP}

Furthermore, we also evaluated the antioxidant stability of HAP in in vitro digestive juice. As shown in Figure 5d, DPPH scavenging rates of HAP maintained at $60 \%-70 \%$ after treatments with pepsin or trypsin although the decrease reached significance. This may be due to the original HAP being further broken by digestive enzymes to form small peptides or free amino acids with lower antioxidant activities (Wang et al., 2016). Indeed, Zhu et al. (2008) reported a similar observation that peptides were hydrolyzed more completely after trypsin digestion, which led to an increase in hydrophilicity, and made it more difficult for the peptides to react with lipid-soluble free radicals. Chen et al. (1998) reported that the hydrophobicity of antioxidants was an important factor in increasing the accessibility of lipophilic fatty acids or oxidants and thus contributes to the expression of antioxidant activity. Digestion might result in a decrease in the biological activity of peptides. Lu et al. (2010) reported that the ACE inhibitory activity of Ile-Gln-Pro only decreased slightly after treatments with pepsin, chymotrypsin, and trypsin 
(a)

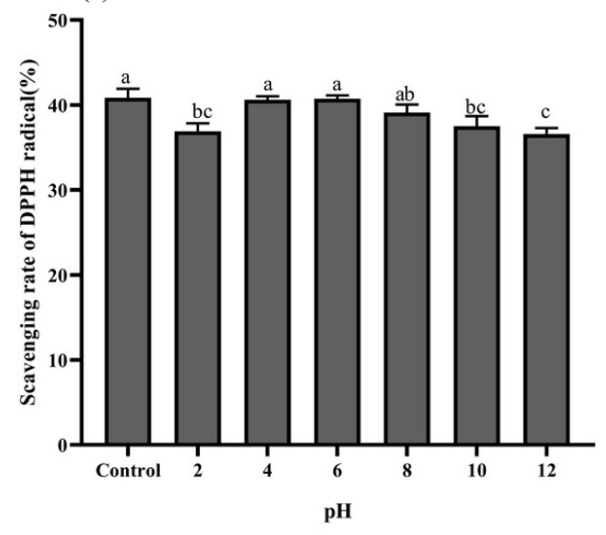

(c)

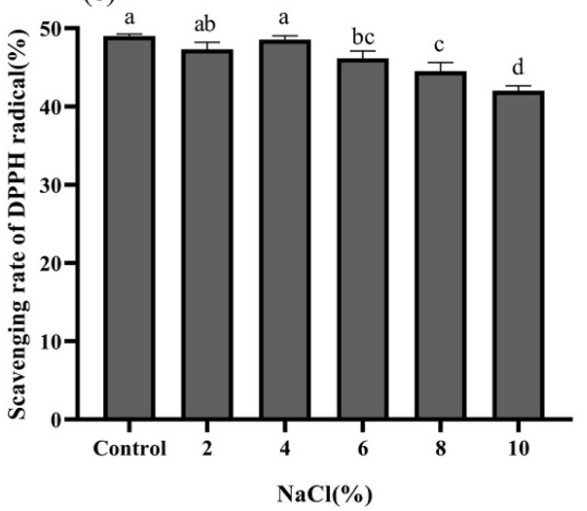

(b)

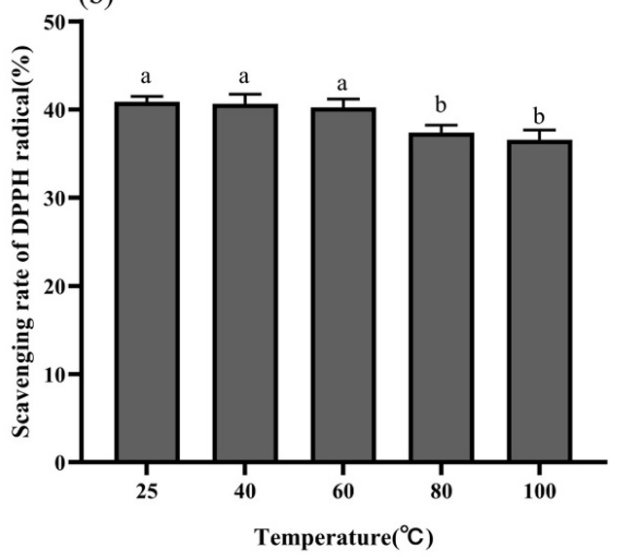

(d)

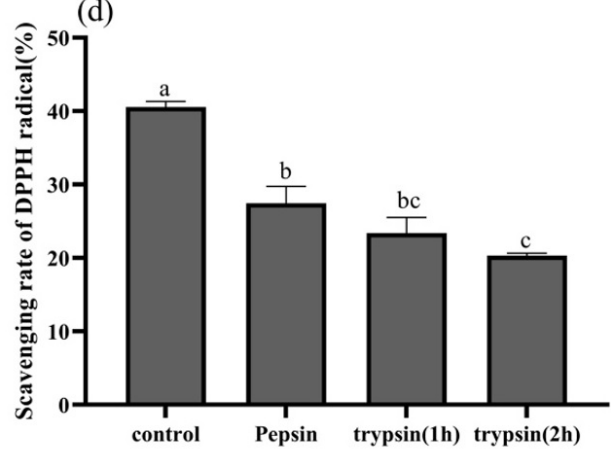

Figure 5. Stability of HAP under different conditions: $\mathrm{pH}$ (a), temperature (b), $\mathrm{NaCl}$ (c) and in vitro gastrointestinal digestion (d).

separately or successively. In a previous study of Zhu et al. (2014), a significantly lower DPPH scavenging rate of Jinhua ham peptides was obtained after trypsin digestion, which supports the results from the present study.

\section{Conclusion}

Enzymatic hydrolysis is among the easiest and most common methods for preparing antioxidant peptides. This process has a number of advantages including low cost, mild reaction condition, easy reaction control, and high product safety, which make it very suitable for industrial large-scale production. In this study, RSM was successfully applied to optimize enzymatic hydrolysis conditions. The highest T-AOC value was obtained from an incubation time of $12.1 \mathrm{~h}$, an incubation temperature of $44.74{ }^{\circ} \mathrm{C}$ and an enzyme concentration of $1858.85 \mathrm{U} / \mathrm{g}$. The amino acid composition of HAP indicated that it is a peptide with strong antioxidant potential. The result of GPC-MALLS analysis showed that HAP contains a main fraction with a Mw of $1.166 \mathrm{kDa}$. Furthermore, we found that $\mathrm{F}_{1}(<3 \mathrm{kDa})$ exerted the greatest antioxidant activity in vitro compared with HAP and other ultrafiltration fractions. Besides, HAP had satisfactory antioxidant stability in wide $\mathrm{pH}$ range, in the presence of $\mathrm{NaCl}$, and upon moderate heating. This may lay a good foundation for HAP to be explored as antioxidant for food and nutraceutical applications. In addition, antioxidant stability of HAP appears to be relatively stable upon in vitro digestion, further study may be needed to explore its in vivo antioxidant activities and possible benefits against oxidative stress in human body. In conclusion, the current research demonstrated hairtail surimi is a good source of antioxidant peptides. Furthermore, these antioxidant peptides showed good stability against heat treatments, different salt concentrations, and in vitro digestion over a wide $\mathrm{pH}$ range, suggesting their possible industrial applications to control oxidative degradation for food preservation.

\section{Acknowledgements}

This work was supported by the International Science and Technology Cooperation Program of Fujian Agriculture and Forestry University (KXGH17001), National Natural Science Foundation of China (31801649) and the China Postdoctoral Science Foundation (2018M63072, 2019T120551), the Research Fund for Taiwan-Straits Postdoctoral Exchange Program (2018B003), and Special Funds for Science and Technology innovation of Fujian Agriculture and Forestry University (CXZX2018063).

\section{References}

Chen, H., Muramoto, K., Yamauchi, F., Fujimoto, K., \& Nokihara, K. (1998). Antioxidative properties of histidine-containing peptides designed from peptide fragments found in the digests of a soybean protein. Journal of Agricultural and Food Chemistry, 46(1), 49-53. http://dx.doi.org/10.1021/jf970649w. PMid:10554195. 
Chi, C., Hu, F., Wang, B., Ren, X., Deng, S., \& Wu, C. (2015). Purification and characterization of three antioxidant peptides from protein hydrolyzate of croceine croaker (Pseudosciaena crocea) muscle. Food Chemistry, 168, 662-667. http://dx.doi.org/10.1016/j. foodchem.2014.07.117. PMid:25172761.

Chouaibi, M., Boussaid, A., Donsì, F., Ferrari, G., \& Hamdi, S. (2018). Optimization of the extraction process by response surface methodology of protein isolate from defatted jujube (zizyphus lotus 1.) seeds. International Journal of Peptide Research and Therapeutics

Fan, J., He, J., Zhuang, Y., \& Sun, L. (2012). Purification and identification of antioxidant peptides from enzymatic hydrolysates of tilapia (oreochromis niloticus) frame protein. Molecules (Basel, Switzerland), 17(11), 12836-12850. http://dx.doi.org/10.3390/molecules171112836. PMid:23117426.

Fang, X., Xie, N., Chen, X., Yu, H., \& Chen, J. (2012). Optimization of antioxidant hydrolysate production from flying squid muscle protein using response surface methodology. Food and Bioproducts Processing, 90(4), 676-682. http://dx.doi.org/10.1016/j.fbp.2012.04.001.

Fu, W., Wang, P., Chen, Y., Lin, J., Zheng, B., Zeng, H., \& Zhang, Y. (2019). Preparation, primary structure and antifreeze activity of antifreeze peptides from Scomberomorus niphonius skin. Lebensmittel-Wissenschaft + Technologie, 101, 670-677. http://dx.doi. org/10.1016/j.lwt.2018.11.067.

Ghassem, M., Arihara, K., Mohammadi, S., Sani, N. A., \& Babji, A. S. (2017). Identification of two novel antioxidant peptides from edible bird's nest (Aerodramus fuciphagus) protein hydrolysate. Food \& Function, 8(5), 8. http://dx.doi.org/10.1039/C6FO01615D. PMid:28497137.

Girgih, A. T., He, R., Hasan, F. M., Udenigwe, C. C., Gill, T. A., \& Aluko, R. E. (2015). Evaluation of the in vitro antioxidant properties of a cod (Gadus morhua) protein hydrolysate and peptide fractions. Food Chemistry, 173, 652-659. http://dx.doi.org/10.1016/j. foodchem.2014.10.079. PMid:25466072.

He, R., Girgih, A. T., Malomo, S. A., Ju, X., \& Aluko, R. E. (2013). Antioxidant activities of enzymatic rapeseed protein hydrolysates and the membrane ultrafiltration fractions. Journal of Functional Foods, 5(1), 219-227. http://dx.doi.org/10.1016/j.jff.2012.10.008.

Huang, S., Lin, H., \& Deng, S. (2015). Study of anti-fatigue effect in rats of ferrous chelates including hairtail protein hydrolysates. Nutrients, 7(12), 9860-9871. http://dx.doi.org/10.3390/nu7125504. PMid:26633476.

Intiquilla, A., Jiménez-Aliaga, K., Guzmán, F., Alvarez, C. A., Zavaleta, A. I., Izaguirre, V., \& Hernández-Ledesma, B. (2019). Novel antioxidant peptides obtained by alcalase hydrolysis of Erythrina edulis (pajuro) protein. Journal of the Science of Food and Agriculture, 99(5), 24202427. http://dx.doi.org/10.1002/jsfa.9449. PMid:30362128.

Jang, H. L., Liceaga, A. M., \& Yoon, K. Y. (2016). Purification, characterisation and stability of an antioxidant peptide derived from sandfish (Arctoscopus japonicus) protein hydrolysates. Journal of Functional Foods, 20, 433-442. http://dx.doi.org/10.1016/j. jff.2015.11.020.

Jin, D., Liu, X., Zheng, X., Wang, X., \& He, J. (2016). Preparation of antioxidative corn protein hydrolysates, purification and evaluation of three novel corn antioxidant peptides. Food Chemistry, 204, 427-436. http://dx.doi.org/10.1016/j.foodchem.2016.02.119. PMid:26988521.

Klompong, V., Benjakul, S., Kantachote, D., \& Shahidi, F. (2007). Antioxidative activity and functional properties of protein hydrolysate of yellow stripe trevally (Selaroides leptolepis) as influenced by the degree of hydrolysis and enzyme type. Food Chemistry, 102(4), 1317-1327. http://dx.doi.org/10.1016/j.foodchem.2006.07.016.
Li, Y-J., Lin, H-M., Deng, S-G., Zhang, H-Q., \& Shi, Y-J. (2016). Genotoxicity and acute oral toxicity of peptides ferrous chelates of hairtail protein. International Journal of Clinical and Experimental Medicine, 9(2), 4047-4052.

Liu, C., Ren, D., Li, J., Fang, L., Wang, J., Liu, J., \& Min, W. (2018). Cytoprotective effect and purification of novel antioxidant peptides from hazelnut (C. heterophylla Fisch) protein hydrolysates. Journal of Functional Foods, 42, 203-215. http://dx.doi.org/10.1016/j. jff.2017.12.003.

Liu, J., Jin, Y., Lin, S., Jones, G. S., \& Chen, F. (2015). Purification and identification of novel antioxidant peptides from egg white protein and their antioxidant activities. Food Chemistry, 175, 258-266. http://dx.doi.org/10.1016/j.foodchem.2014.11.142. PMid:25577078.

Liu, Y., Wan, S., Liu, J., Zou, Y., \& Liao, S. (2017). Antioxidant activity and stability study of peptides from enzymatically hydrolyzed male silkmoth. Journal of Food Processing and Preservation, 41(1), e13081. http://dx.doi.org/10.1111/jfpp.13081.

Lu, J., Ren, D., Xue, Y., Sawano, Y., Miyakawa, T., \& Tanokura, M. (2010). Isolation of an antihypertensive peptide from alcalase digest of spirulina platensis. Journal of Agricultural and Food Chemistry, 58(12), 7166-7171.

Meshginfar, N., Sadeghi Mahoonak, A., Hosseinian, F., Ghorbani, M., \& Tsopmo, A. (2018). Production of antioxidant peptide fractions from a by-product of tomato processing: mass spectrometry identification of peptides and stability to gastrointestinal digestion. Journal of Food Science and Technology, 55(9), 3498-3507. http://dx.doi.org/10.1007/ s13197-018-3274-z. PMid:30150808.

Oliyai, C., \& Borchardt, R. T. (1993). Chemical pathways of peptide degradation. iv. pathways, kinetics, and mechanism of degradation of an aspartyl residue in a model hexapeptide. Pharmaceutical Research, 10(1), 95-102. http://dx.doi.org/10.1023/A:1018981231468. PMid:8430066.

Park, S. Y., Lee, J.-S., Baek, H.-H., \& Lee, H. G. (2010). Purification and characterization of antioxidant peptides from soy protein hydrolysate. Journal of Food Biochemistry, 34(s1), 120-132. http:// dx.doi.org/10.1111/j.1745-4514.2009.00313.x.

Patel, K., \& Borchardt, R. T. (1990). Chemical pathways of peptide degradation. II. kinetics of deamidation of an asparaginyl residue in a model hexapeptide. Pharmaceutical Research, 7(7), 703-711. http://dx.doi.org/10.1023/A:1015807303766. PMid:2395797.

Ren, J., Zhao, M., Shi, J., Wang, J., Jiang, Y., Cui, C., Kakuda, Y., \& Xue, S. J. (2008). Optimization of antioxidant peptide production from grass carp sarcoplasmic protein using response surface methodology. Lebensmittel-Wissenschaft + Technologie, 41(9), 1624-1632. http:// dx.doi.org/10.1016/j.lwt.2007.11.005.

Sun, L., Zhang, Y., \& Zhuang, Y. (2013). Antiphotoaging effect and purification of an antioxidant peptide from tilapia (Oreochromis niloticus) gelatin peptides. Journal of Functional Foods, 5(1), 154162. http://dx.doi.org/10.1016/j.jff.2012.09.006.

Taheri, A., Sabeena Farvin, K. H., Jacobsen, C., \& Baron, C. P. (2014). Antioxidant activities and functional properties of protein and peptide fractions isolated from salted herring brine. Food Chemistry, 142, 318-326. http://dx.doi.org/10.1016/j.foodchem.2013.06.113. PMid:24001848.

Tanzadehpanah, H., Asoodeh, A., \& Chamani, J. (2012). An antioxidant peptide derived from Ostrich (Struthio camelus) egg white protein hydrolysates. Food Research International, 49(1), 105-111. http:// dx.doi.org/10.1016/j.foodres.2012.08.022.

Tiroli-Cepeda, A. O., Seraphim, T. V., Pinheiro, G. M. S., Souto, D. E. P., Kubota, L. T., Borges, J. C., Barbosa, L. R. S., \& Ramos, C. H. I. (2018). Studies on the effect of the J-domain on the substrate binding 
domain (SBD) of Hsp70 using a chimeric human J-SBD polypeptide. International Journal of Biological Macromolecules, 124, 111-120. http://dx.doi.org/10.1016/j.ijbiomac.2018.11.130. PMid:30458192.

Wang, B., Li, L., Chi, C., Ma, J., Luo, H., \& Xu, Y. (2013). Purification and characterisation of a novel antioxidant peptide derived from blue mussel (Mytilus edulis) protein hydrolysate. Food Chemistry, 138(2), 1713-1719. http://dx.doi.org/10.1016/j.foodchem.2012.12.002. PMid:23411302.

Wang, C., Wang, B., \& Li, B. (2016). Bioavailability of peptides from casein hydrolysate in vitro: Amino acid compositions of peptides affect the antioxidant efficacy and resistance to intestinal peptidases. Food Research International, 81, 188-196. http://dx.doi.org/10.1016/j. foodres.2015.12.013.

Wang, L., Sun, J., Ding, S., \& Qi, B. (2018). Isolation and identification of novel antioxidant and antimicrobial oligopeptides from enzymatically hydrolyzed anchovy fish meal. Process Biochemistry, 74, 148-155. http://dx.doi.org/10.1016/j.procbio.2018.08.021.

Wiriyaphan, C., Xiao, H., Decker, E. A., \& Yongsawatdigul, J. (2015). Chemical and cellular antioxidative properties of threadfin bream (Nemipterus spp.) surimi byproduct hydrolysates fractionated by ultrafiltration. Food Chemistry, 167, 7-15. http://dx.doi.org/10.1016/j. foodchem.2014.06.077. PMid:25148952.

Wu, H., Chen, H., \& Shiau, C. (2003). Free amino acids and peptides as related to antioxidant properties in protein hydrolysates of mackerel (Scomber austriasicus). Food Research International, 36(9-10), 949957. http://dx.doi.org/10.1016/S0963-9969(03)00104-2.

Xue, Z., Wen, H., Zhai, L., Yu, Y., Li, Y., Yu, W., Cheng, A., Wang, C., \& Kou, X. (2015). Antioxidant activity and anti-proliferative effect of a bioactive peptide from chickpea (Cicer arietinum L.).
Food Research International, 77, 75-81. http://dx.doi.org/10.1016/j. foodres.2015.09.027.

Yang, X.-R., Zhang, L., Ding, D.-G., Chi, C.-F., Wang, B., \& Huo, J.-C. (2019). Preparation, identification, and activity evaluation of eight antioxidant peptides from protein hydrolysate of hairtail (trichiurus japonicas) muscle. Marine Drugs, 17(1), 23. http://dx.doi.org/10.3390/ md17010023. PMid:30609694.

Ye, Z., Zhang, H., Luo, H., Wang, S., Zhou, Q., Du, X., Tang, C., Chen, L., Liu, J., Shi, Y. K., Zhang, E. Y., Ellis-Behnke, R., \& Zhao, X. (2008). Temperature and $\mathrm{pH}$ effects on biophysical and morphological properties of self-assembling peptide RADA16-I. Journal of Peptide Science: an Official Publication of the European Peptide Society, 14(2), 152-162. http://dx.doi.org/10.1002/psc.988.

Yuan, G., Li, W., Pan, Y., Wang, C., \& Chen, H. (2018). Shrimp shell wastes: optimization of peptide hydrolysis and peptide inhibition of a-amylase. Food Bioscience, 25, 52-60. http://dx.doi.org/10.1016/j. fbio.2018.07.008.

Zheng, Z., Si, D., Ahmad, B., Li, Z., \& Zhang, R. (2018). A novel antioxidative peptide derived from chicken blood corpuscle hydrolysate. Food Research International, 106, 410-419. http://dx.doi. org/10.1016/j.foodres.2017.12.078. PMid:29579942.

Zhu, C., Zhang, W., Kang, Z., Zhou, G., \& Xu, X. (2014). Stability of an antioxidant peptide extracted from Jinhua ham. Meat Science, $96(2$ Pt A), 783-789. http://dx.doi.org/10.1016/j.meatsci.2013.09.004. PMid:24200571.

Zhu, L., Chen, J., Tang, X., \& Xiong, Y. L. (2008). Reducing, radical scavenging, and chelation properties of in vitro digests of alcalasetreated zein hydrolysate. Journal of Agricultural and Food Chemistry, 56(8), 2714-2721. http://dx.doi.org/10.1021/jf703697e. PMid:18376842. 


\section{Supplementary Material}

Supplementary material accompanies this paper.

Supplementary Table 1. Parameters for Enzymatic Hydrolysis of Hairtail Surimi

Supplementary Table 2. Single-factor scheme

Supplementary Table 3. Factors and Levels in the RSM Experimental Design

Supplementary Table 4. Experimental Design used in RSM Studies and Responses for the Optimization of HAP

This material is available as part of the online article from http://www.scielo.br/cta 